\title{
STCR-Based Manure and Fertilizers Application Effect on Performance of Rice and Chemical Properties of Vertisol
}

\author{
Saroj Choudhary $^{1 *}$, S.S. Baghel ${ }^{2}$, A.K. Upadhyay ${ }^{2}$ and Arjun Singh $^{3}$ \\ ${ }^{1}$ Department of SSAC, BHU, Varanasi (U.P.) - 221005, India \\ ${ }^{2}$ Department of Soil Science and Agricultural Chemistry, JNKVV, \\ Jabalpur (M.P.) - 482004, India \\ ${ }^{3}$ Division of Agronomy, IARI, New Delhi-110012, India \\ *Corresponding author
}

\begin{abstract}
A B S T R A C T
An experiment was conducted at soil science research farm of Jawaharlal Nehru Krishi

Keywords

STCR- Based

Manure and

Fertilizers,

Vertisol

Vishwa Vidyalaya, Jabalpur, to study the effect of STCR-based manure and fertilizers application on growth and yield of rice, and changes in chemical properties of soil. Experiment was carried out during kharif season of 2016. Experiment was laid out in Randomized Block Design, consisting of four replications and six treatments viz., $\mathrm{T}_{1}$ : Absolute control, $\mathrm{T}_{2}$ : GRD, $\mathrm{T}_{3}$ : Targeted yield $50 \mathrm{qha}^{-1}, \mathrm{~T}_{4}$ : Targeted yield $60 \mathrm{qha}^{-1}, \mathrm{~T}_{5}$ : Targeted yield $50 \mathrm{qha}^{-1}$ with $5 \mathrm{t} \mathrm{FYM} \mathrm{ha}{ }^{-1}$ and $\mathrm{T}_{6}$ : Targeted yield $60 \mathrm{qha}^{-1}$ with $5 \mathrm{t} \mathrm{FYM}$

Article Info

Accepted:

15 February 2019

Available Online:

10 March 2019 $\mathrm{ha}^{-1}$. The result revealed that rice growth parameters and grain yield was significantly affected due to fertilizers and manure application and recorded highest yield in treatment $\mathrm{T}_{6}\left(5725 \mathrm{~kg} \mathrm{ha}^{-1}\right)$ which was significantly superior to control. The chemical properties viz available nitrogen, phosphorus and potassium were found significantly higher as compared to control. Hence, it can be concluded that integrated use of NPK fertilizer with FYM based on STCR approach not only gave higher rice yield but also improve and sustain the soil fertility.
\end{abstract}

\section{Introduction}

Rice (Oryza sativa L.) is the staple food of millions of people and provides about 700 calories/day/person for about 3000 million people living mostly in developing countries (Singh et al., 2017). It is the grain that has shaped the cultures, diets and economics of billions of people in the world (Farooq et al., 2009). Paddy is a staple food crop in south, south-east and east-Asia where about $90 \%$ of world's paddy is grown and consumed. The country need to exaggerate its food grain production to 450 million tons $(\mathrm{mt})$ at the end of the year 2050 to maintain its food security, this means country need to add $166 \mathrm{mt}$ to its current production level of $284 \mathrm{mt}$ (MoAFW, 2018). In India rice alone contributes about 43 percent into the countries food grain basket. This proclaims the addition of rice in meeting 
food requirements of the starving mouth of country. Yield of rice depends on several factors like genotype, edaphic, climatic and management. Imbalanced fertilization of major nutrients is one of the reasons for lower production of rice in India (Reddy and Ahmed, 2000). Fertilizer is one of the most important and expensive inputs in agriculture and the application of correct amount of fertilizer is primary prerequisite for farm profitability and environmental safety (Kimetu et al., 2004).

In India, fertilizers are generally applied to crops on the basis of generalized state level fertilizer recommendations, though the nutrient requirement of crops vary from place to place even for the same crop, as the fertility is highly variable chemical property of the soils. Fertilization of crops based on generalized recommendation leads to under fertilization or over fertilization, results in lower productivity, profitability along with environmental pollution.

Among the various scientific methods of fertilizer recommendation, which incorporate soil test values, nutrient requirement of the crop, contribution of nutrients from soil, manures, fertilizers and fixing yield-targets is only the Soil Test Crop Response (STCR) approach (Regar and Singh, 2014). Fertilizer recommendation based on yield target was first initiated by Troug (1960), which later modified by Ramomoorthy et al., (1967) to suit the Indian condition. It provides a scientific basis for balanced fertilisation and balance between applied nutrients and soil available nutrients (Ramamoorthy and Velayutham, 2011). Soil test based application of plant nutrient helps to understand higher comeback ratio and benefit: cost ratio as the nutrients are applied in proportion to the amount of the deficiency of a particular nutrient and the correction of the nutrients imbalance in soil helps to harness the synergistic effects of balanced fertilization (Rao and Srivastava, 2000). The present investigation aimed to study the relationship between the nutrient supplied by the soil and added fertilizers, their uptake and yield of paddy and to develop a guideline for judicious application of fertilizer for maximum production of paddy.

\section{Materials and Methods}

This study was under taken in an ongoing AICRP on STCR project, JNKVV, Jabalpur (M.P.). The present investigation was carried out in Kharif season in 2016 with the test crop rice (Kranti variety) at the soil science research farm of Jawaharlal Nehru Krishi Vishwa Vidyalaya, Jabalpur, situated in the South-Eastern part of the Madhya Pradesh at $23^{0} 13^{\prime}$ North latitude, $79^{0} 57^{\prime}$ East longitudes and at an elevation of 393 meter above mean sea level. The soil of the experimental site was Vertisol (medium black) belongs to Kheri series of fine montmorillonitic hyperthermic family of Typic Haplusterts. The initial physico-chemical properties of preexperimental surface $(0-15 \mathrm{~cm})$ soil were presented in Table 1.

The experiment was laid out in randomized block design (RBD) with four replications consisting of 6 treatments combinations viz; $\mathrm{T}_{1}$ : Absolute control; $\mathrm{T}_{2}$ : General recommended dose (120:60:40 $\mathrm{kg} \mathrm{N}, \mathrm{P}_{2} \mathrm{O}_{5}$ and $\mathrm{K}_{2} \mathrm{O}$ ha $\left.^{-1}\right) ; \mathrm{T}_{3}$ : Targeted yield $50 \mathrm{q} \mathrm{ha}^{-1}$ (115:90:49 $\mathrm{kg} \mathrm{N}, \mathrm{P}_{2} \mathrm{O}_{5}$ and $\left.\mathrm{K}_{2} \mathrm{O} \mathrm{ha}^{-1}\right) ; \mathrm{T}_{4}$ : Targeted yield $60 \mathrm{q} \mathrm{ha}^{-1}(157: 125: 70 \mathrm{~kg} \mathrm{~N}$, $\mathrm{P}_{2} \mathrm{O}_{5}$ and $\mathrm{K}_{2} \mathrm{O}$ ha $^{-1}$ ); $\mathrm{T}_{5}$ : Targeted yield $50 \mathrm{q}+$ 5 t FYM ha ${ }^{-1}$ (115:90:49 $\mathrm{kg} \mathrm{N}, \mathrm{P}_{2} \mathrm{O}_{5}$ and $\mathrm{K}_{2} \mathrm{O}$ $\left.\mathrm{ha}^{-1}\right) ; \mathrm{T}_{6}$ : Targeted yield $60 \mathrm{q}+5 \mathrm{t} \mathrm{FYM} \mathrm{ha}^{-1}$ (157:125:70 kg N, $\mathrm{P}_{2} \mathrm{O}_{5}$ and $\mathrm{K}_{2} \mathrm{O}$ ha $^{-1}$ ).

Fertilizer prescription equations for rice developed under AICRP on STCR, Jabalpur, given below, are used for the calculation of the doses of fertilizer and manure. 
$\mathrm{FN}=4.25 \mathrm{~T}-0.45 \mathrm{SN}$

$\mathrm{FP}_{2} \mathrm{O}_{5}=3.55 \mathrm{~T}-4.89 \mathrm{SP}$

$\mathrm{FK}_{2} \mathrm{O}=2.10 \mathrm{~T}-0.18 \mathrm{SK}$

Where, $\mathrm{FN}, \mathrm{FP}_{2} \mathrm{O}_{5}$ and $\mathrm{FK}_{2} \mathrm{O}$ are fertilizer $\mathrm{N}$, $\mathrm{P}_{2} \mathrm{O}_{5}$ and $\mathrm{K}_{2} \mathrm{O}$ in $\mathrm{kg} \mathrm{ha}{ }^{-1}$, respectively; $\mathrm{T}=$ targeted grain yield in $\mathrm{q} \mathrm{ha}^{-1}, \mathrm{SN}, \mathrm{SP}$ and $\mathrm{SK}$ are soil available $\mathrm{N}, \mathrm{P}$ and $\mathrm{K}$ in $\mathrm{kg} \mathrm{ha}^{-1}$ respectively.

\section{Data collection}

Plant height at different crop growth stages (30, 60, 90 DAS and at harvest) was recorded from five tagged rice plants which were selected randomly from net plot area. Plant height is taken from the base of the plant to the tip of the top most leaf with the help of measuring scale and the average is expressed in $\mathrm{cm}$., while the number of tillers also counted in the same plants and average values are expressed at their respective crop growth stages. After harvesting, panicles are grouped into bundles according to the imposed treatments, allowed to dry in the field till it obtained constant weight. The threshing of panicles from different treatments was done manually followed by recording the grain and straw yield $\left(\mathrm{kg} \mathrm{ha}^{-1}\right)$.Soil samples has been collected from the experimental plots for soil nutrient analysis.

\section{Statistical analysis}

The data pertaining to each character of the rice crop were tabulated and analyzed statistically by applying the standard technique. Analysis of variance for randomized block design was worked out and the significance of treatments were tested to draw valid conclusions as described by Gomez and Gomez (1984). The differences of treatments mean were tested by ' $F$ ' test of significance on the basis of null hypothesis. Critical differences were worked out at 5 percent level of probability where ' $F$ ' test was significant. If the variance ratios (F-test) were found significant at $5 \%$ level of significance, the standard error of mean (SEm) and critical differences (CD) were calculated accordingly.

\section{Results and Discussion}

\section{Plant height}

Data revealed that there was marked significant difference in plant height at various treatments at all the stages except 30 DAS where it did not differ significantly (Table 2). The maximum plant height (viz., 30.95, 59.17, 76.61 and $76.33 \mathrm{~cm}$ at 30 DAS, 60 DAS, 90 DAS and at harvest, respectively) were recorded in treatment $\mathrm{T}_{6}$ where highest NPK levels integrated with FYM (157:125:70 kg N: $\mathrm{P}_{2} \mathrm{O}_{5}: \mathrm{K}_{2} \mathrm{O}+5 \mathrm{t} \mathrm{FYM} \mathrm{ha}^{-1}$ ) were applied, while it was found minimum under control at all the stages. The progressive increase in plant height might be due to the fact that the demand of NPK levels with FYM have been sufficient for the formation of chlorophyll and nucleic acids which are responsible for growth and development (Srivastava et al., 2013). The findings are in accordance with the results reported by, Challa Venureddy (2014) and Mahmud et al., (2016).

\section{Number of tillers per plant}

STCR-based application of fertilizers and manure leads to the statistically significant variation in number of tillers plant ${ }^{-1}$ at all growth stages (Table 2). It is evident from the data that number of tillers were increased with increasing levels of NPK with FYM. At early growth stage (30 DAS), the treatment $\mathrm{T}_{6}$ (157:125:70 kg N: $\mathrm{P}_{2} \mathrm{O}_{5}: \mathrm{K}_{2} \mathrm{O}+5$ t FYM ha ${ }^{-1}$ ) brought significantly maximum number of tillers (2.85) over control. Whereas, minimum number of tillers were recorded (1.97) in treatment $\mathrm{T}_{1}$ (control). At 60 DAS the significantly maximum number of tillers (7.75) were recorded in treatment $\mathrm{T}_{6}$ (157:125:70 kg N: $\left.\mathrm{P}_{2} \mathrm{O}_{5}: \mathrm{K}_{2} \mathrm{O}+5 \mathrm{t} \mathrm{ha}^{-1} \mathrm{FYM}\right)$ which were statistically at par with rest of 
treatment except control. However, the minimum number of tillers (4.13) was recorded in treatment $\mathrm{T}_{1}$. At $90 \mathrm{DAS}$, the maximum number of tillers (8.67) were recorded in treatment $\mathrm{T}_{6}(157: 125: 70 \mathrm{~kg} \mathrm{~N}$ : $\mathrm{P}_{2} \mathrm{O}_{5}: \mathrm{K}_{2} \mathrm{O}+5 \quad \mathrm{t} \quad \mathrm{ha}^{-1} \mathrm{FYM}$ ) which was significant over rest of the treatments except $\mathrm{T}_{3}, \mathrm{~T}_{4}$ and $\mathrm{T}_{5}$. The minimum number of tillers (4.65) was recorded in treatment $\mathrm{T}_{1}$ (control). At harvest, the number of tillers slightly decreases. The maximum number of tillers (8.51) were also recorded in $\mathrm{T}_{6}$ (T.Y.6 $\mathrm{t} \mathrm{ha}^{-1}+$ $5 \mathrm{t} \mathrm{ha}^{-1} \mathrm{FYM}$ ) which was significant over all the treatments but at par with $\mathrm{T}_{4}$ and $\mathrm{T}_{5}$ whereas, the minimum number of tillers (4.19) were recorded in treatment $T_{1}$, followed by $T_{2}$ (7.51), respectively. The increment in number of tillers with NPK and FYM can be attributed to soil conditions with more availability and uptake of nutrients, water and growth promoting substances to promote more tillers. Similar findings have been also reported by Srivastava et al., (2013), Tabar et al., (2012) and Mahmud et al., (2016).

\section{Grain yield}

Grain yield of rice was significantly influenced by different level of fertilizers and manure application based on STCR approach. Maximum grain yield viz. 5725, 5213, 5371, 4819 and $4237 \mathrm{~kg} \mathrm{ha}^{-1}$ was recorded with treatment $\mathrm{T}_{6}, \mathrm{~T}_{5}, \mathrm{~T}_{4}, \mathrm{~T}_{3}$ and $\mathrm{T}_{2}$ respectively.

However, Treatment $T_{6}, T_{5}$ and $T_{4}$ are at par and were significantly different from $\mathrm{T}_{1}, \mathrm{~T}_{2}$ and $\mathrm{T}_{3}$. Minimum grain yield of $2781 \mathrm{~kg} \mathrm{ha}^{-1}$ was found under control. Higher yield in $T_{6}$ and $\mathrm{T}_{5}$ might be due to the integrated application of NPK fertilizers and FYM, which enhance the nutrient availability throughout the growing season (Table 3). Similar findings were also reported by Subehia and Sepehya (2012), Gautam et al., (2013), Kumar et al., (2014) and Mahmud et al., (2016).

\section{Chemical properties}

The residual available nitrogen content at both the stages under different treatments varied from 181.45 to 253.39 and 153.21 to 211.67 $\mathrm{kg} \mathrm{ha}{ }^{-1}$ at 60 DAS and at harvest soil, respectively, against the initial values of $217.83 \mathrm{~kg} \mathrm{ha}^{-1}$ (Table 3).

Table.1 Initial Chemical properties of experimental soil at 0-15 cm depth

\begin{tabular}{|l|c|l|}
\hline \multicolumn{1}{|c|}{ Particulars } & \multicolumn{2}{c|}{ Method employed } \\
\cline { 2 - 3 } & $0-15 \mathrm{~cm}$ & \multicolumn{1}{c|}{ Method } \\
\hline $\begin{array}{l}\text { Soil } \mathrm{pH} \\
\left(\mathrm{pH} \mathrm{w} 1: 2.5 \text { at } 25^{0} \mathrm{C}\right)\end{array}$ & 7.57 & $\begin{array}{l}\text { Glass electrode } \mathrm{pH} \text { meter } \\
\text { (Jakson, 1973) }\end{array}$ \\
\hline $\begin{array}{l}\text { Electrical Conductivity } \\
\left(\mathrm{dS} \mathrm{m}^{-1} \text { at } 25^{0} \mathrm{C}\right)\end{array}$ & 0.321 & $\begin{array}{l}\text { Electrical conductivity meter } \\
\text { (Jakson, 1973) }\end{array}$ \\
\hline $\begin{array}{l}\text { Organic Carbon } \\
\left(\mathrm{g} \mathrm{kg}^{-1}\right)\end{array}$ & 217.83 & $\begin{array}{l}\text { Potassium dichromate rapid titration method (Walkley and } \\
\text { Black, 1934) }\end{array}$ \\
\hline $\begin{array}{l}\text { Available Nitrogen } \\
\left(\mathrm{kg} \mathrm{ha}^{-1}\right)\end{array}$ & 21.45 & $\begin{array}{l}\text { Alkaline permanganate method } \\
\text { (Subbiah and Asija, 1956) }\end{array}$ \\
\hline $\begin{array}{l}\text { Available Phosphorus } \\
\left(\mathrm{kg} \mathrm{ha}^{-1}\right)\end{array}$ & 311.57 & $\begin{array}{l}\text { Soil extracted with 0.5 M NaHCO } \text { and colour development by } \\
\text { ascorbic acid } \\
\text { (Watanabe and Olsen s, 1965) }\end{array}$ \\
\hline $\begin{array}{l}\text { Available Potassium } \\
\left(\mathrm{kg} \mathrm{ha}^{-1}\right)\end{array}$ & $\begin{array}{l}\text { Neutral normal ammonium acetate method by using Flame } \\
\text { photometer } \\
\text { (Hanway and Heidel, 1952) }\end{array}$ \\
\hline
\end{tabular}


Table.2 Effect of STCR- based manures and fertilizers recommendation on plant height, number of tillers and yield of rice

\begin{tabular}{|c|c|c|c|c|c|c|c|c|c|}
\hline \multirow[t]{2}{*}{ Treatment } & \multicolumn{4}{|c|}{ Plant height $(\mathrm{cm})$} & \multicolumn{4}{|c|}{ Number of tillers/plant } & \multirow{2}{*}{$\begin{array}{l}\text { Grain } \\
\text { yield } \\
\mathrm{kg} / \mathrm{ha}\end{array}$} \\
\hline & $\begin{array}{c}30 \\
\text { DAS }\end{array}$ & $\begin{array}{c}60 \\
\text { DAS }\end{array}$ & $\begin{array}{c}90 \\
\text { DAS }\end{array}$ & Harvest & $\begin{array}{c}30 \\
\text { DAS }\end{array}$ & $\begin{array}{c}60 \\
\text { DAS }\end{array}$ & $\begin{array}{c}90 \\
\text { DAS }\end{array}$ & Harvest & \\
\hline $\mathrm{T}_{1}$ & 28.81 & 44.68 & 51.43 & 50.57 & 1.97 & 4.13 & 4.65 & 4.19 & 2781 \\
\hline $\mathrm{T}_{2}$ & 29.13 & 51.71 & 65.57 & 64.93 & 2.43 & 6.81 & 7.53 & 7.15 & 4237 \\
\hline $\mathrm{T}_{3}$ & 29.43 & 53.79 & 68.31 & 67.75 & 2.59 & 7.13 & 7.98 & 7.69 & 4819 \\
\hline $\mathrm{T}_{4}$ & 30.19 & 57.33 & 73.13 & 72.73 & 2.77 & 7.57 & 8.46 & 8.27 & 5371 \\
\hline $\mathrm{T}_{5}$ & 29.87 & 55.85 & 71.55 & 71.11 & 2.69 & 7.33 & 8.21 & 7.95 & 5213 \\
\hline $\mathrm{T}_{6}$ & 30.95 & 59.17 & 76.61 & 76.33 & 2.85 & 7.75 & 8.67 & 8.51 & 5725 \\
\hline SEm \pm & 1.05 & 1.72 & 2.07 & 1.95 & 0.10 & 0.22 & 0.25 & 0.24 & 219 \\
\hline $\mathrm{CD}_{(p=0.05)}$ & NS & 5.29 & 6.39 & NS & 0.31 & 0.69 & 0.77 & 0.73 & 675 \\
\hline
\end{tabular}

Table.3 Effect of different treatments on available major nutrient content in soil

\begin{tabular}{|c|c|c|c|c|c|c|}
\hline \multirow[t]{2}{*}{ Treatments } & \multicolumn{2}{|c|}{$\begin{array}{l}\text { Available Nitrogen } \\
\left(\mathrm{kg} \mathrm{ha}^{-1}\right)\end{array}$} & \multicolumn{2}{|c|}{$\begin{array}{l}\text { Available } \\
\text { Phosphorus } \\
\left(\mathrm{kg} \mathrm{ha}^{-1}\right)\end{array}$} & \multicolumn{2}{|c|}{$\begin{array}{l}\text { Available Potassium } \\
\left(\mathrm{kg} \mathrm{ha}^{-1}\right)\end{array}$} \\
\hline & $\begin{array}{c}60 \\
\text { DAS }\end{array}$ & At Harvest & $\begin{array}{c}60 \\
\text { DAS }\end{array}$ & $\begin{array}{c}\text { At } \\
\text { harvest }\end{array}$ & $\begin{array}{c}60 \\
\text { DAS }\end{array}$ & $\begin{array}{c}\text { At } \\
\text { Harvest }\end{array}$ \\
\hline $\mathrm{T}_{1}$ : & 181.45 & 153.21 & 15.73 & 11.27 & 257.53 & 223.67 \\
\hline $\mathrm{T}_{2}$ & 225.63 & 187.65 & 22.37 & 18.45 & 273.97 & 257.43 \\
\hline $\mathrm{T}_{3}$ & 231.27 & 181.43 & 23.91 & 20.71 & 278.65 & 251.35 \\
\hline $\mathrm{T}_{4}$ & 243.51 & 199.77 & 26.43 & 23.69 & 285.39 & 265.59 \\
\hline $\mathrm{T}_{5}$ & 239.83 & 193.59 & 27.85 & 25.17 & 289.41 & 267.23 \\
\hline $\mathrm{T}_{6}$ & 253.39 & 211.67 & 30.17 & 27.53 & 297.25 & 279.31 \\
\hline $\mathrm{SE} \mathrm{m} \pm$ & 5.37 & 4.83 & 0.75 & 0.55 & 6.97 & 6.41 \\
\hline $\mathrm{CD}_{(p=0.05)}$ & 16.53 & 14.87 & 2.31 & 1.69 & 21.47 & 19.73 \\
\hline
\end{tabular}

The lowest residual $\mathrm{N}$ in control $\left(\mathrm{T}_{1}\right)$ shows that $\mathrm{N}$ was depleted in the soil and crop used the indigenous soil nitrogen which claims the depletion of soil fertility, in contrast to this, residual $\mathrm{N}$ content at harvest in soil in $\mathrm{T}_{6}$ was at par with that of initial $\mathrm{N}$ level. Thus, it can be supposed that $\mathrm{T}_{6}$ was more beneficial for improving and sustaining the soil fertility. Higher residual nutrient in $\mathrm{T}_{6}$ might be due to the incorporation of fertilizers with organic manure brought about increased availability of nutrient in soil solution exceeding the demand of crop plant. Similar results were also reported by Subehia (2012) and Habtamu (2015). Similarly, the increasing levels of NP-K with and without FYM caused significant improvement in available phosphorus at 60 DAS and at harvest of rice crop. It is clearly evident from the data that application of N-P$\mathrm{K}$ nutrients integrated with FYM significantly increased the content of available $\mathrm{P}$ at both the stages over without inorganic nutrients. The maximum available phosphorus was found in $\mathrm{T}_{6}$ (30.17 and $27.53 \mathrm{~kg} \mathrm{ha}^{-1}$ at 60 DAS and at harvest, respectively) and minimum observed in $\mathrm{T}_{1}(15.73$ and $11.27 \mathrm{~kg}$ $\mathrm{ha}^{-1}$ at 60 DAS and at harvest, respectively). Garg and Milkha (2010) reported the increasing levels of $\mathrm{P}$ application continuously either alone or with organic manure improved the available $\mathrm{P}$ status. While potassium is not a fundamental element 
of plant but it is mandatory in huge quantity almost equal to $\mathrm{N}$. It may be seen from the data that the available potassium content increased with the application of NPK fertilizers with and without integration of FYM as compared to control. The data of available potassium as influenced by various treatments at both the stages indicated that the status of available potassium was higher in all the treatments over control, it varied from $257.53 \mathrm{~kg} \mathrm{ha}^{-1}$ to $297.25 \mathrm{~kg} \mathrm{ha}^{-1}$ at $60 \mathrm{DAS}$ and $223.67 \mathrm{~kg} \mathrm{ha}^{-1}$ to $279.31 \mathrm{~kg} \mathrm{ha}^{-1}$ at harvest soil. Results were in accordance with that of Laxminarayana (2006). It is evident from the above data that STCR based fertilizer and manures application not only increase the growth and yield of rice but also improved and sustained the soil fertility.

\section{References}

Challa, Venureddy. 2014. Effect of continuous application of fertilizers and manures on soil physical properties, nutrient uptake, growth and yield of rice on Chromustert. Indian Journal of Agronomy. 3: 22-31

Farooq, M., Wahid A., Kobayashi, D.N., Fujita, S., Basra, M.A. 2009. Plant drought stress. Effects, mechanisms and management. Agronomy for Sustainable Development. 29: 185-212.

Garg, A.K. and Milkha, S.A. 2010. Effect of long term fertilizer management and crop rotation on accumulation and downward movement of phosphorus in semi-arid subtropical irrigated soil. Communication in Soil Sci. and Plant Ana. 41: 848-864.

Gautam, P., Sharma, G.D., Rachana, R. and Lal, B. 2013. Effect of integrated nutrient management and spacing on growth parameters, nutrient content and productivity of rice under system of rice intensification. International Journal of Research in BioSciences. 2(3): 53-59.
Habtamu, A.D. 2015. Effects of organic and inorganic fertilizers on selected soil properties after harvesting maize at Antra Catchment, Northwestern Ethiopia. International Inv. Journal of Agriculture Soil Science 3(5): 68-78.

Hanway, J.J. and Heidel, H. 1952. Soil Analysis Methods, as used in Iowa State. College Soil Testing Laboratory, Iowa, Agriculture 57: 1-31.

Jackson, M.L. 1973. Soil Chemical Analysis. Prentice Hall of India Pvt. Ltd., New Delhi.

Kimetu, M., Mugendi, D. N., Palm, C. A., Mutuo, P. K., Gachengo, C. N., Nandwa, S. and Kungu, B. 2004. African network on soil biology and fertility.(http://www.ciat.cgiar.org/\#afne cbook). pp. 207- 224.

Kumar, A., Meena, R.N., Yadav, L. and Gilotyia, Y.K. 2014. Effect of organic and inorganic sources of nutrient on yield, yield attributes and nutrient uptake of rice. The Bio-scan 9(2): 595597.

Laximinarayana, K. 2006. Effect of integrated use of inorganic and organic manures on soil properties, yield and nutrient uptake of rice in Ultisols of Mizoram. Journal of Indian Society of Soil Science 54(1): 120-123.

Mahmud, A.J., Shamsuddoha, A.T.M. and Nazmul, H.M. 2016. Effect of Organic and Inorganic Fertilizer on the Growth and Yield of Rice (Oryza sativa L.). Nature and Science 14(2): 45-54.

MoAFW. 2018. Agricultural Statistics Division, Directorate of Economics and Statistics. Ministry of Agriculture and Farmer Welfare, Govt. of India. GOI. http://pibphoto.nic.in/documents/rlink/2 017/may/p20175902.pdf.

Watanabe, F.S. and Olsen, S.R. 1965. Test of an ascorbic acid method for determining phosphorus in water and $\mathrm{NaHCO} 3$ extracts from soil. Soil Science Society 
of America Proceedings 29: 677-678.

Ramamoorthy, B., Narsimham, R.L. and Dinesh, R.S. 1967. Fertilizer application for specific yield targets of Sonara-64. Indian Farming 17: 43-45.

Ramamoorthy, B. and Velayutham, M. 2011. The "Law of optimum" and soil test based fertilizer use for targeted yield of crops and soil fertility management for sustainable agriculture. Madras Agric. J. 98: 295-307.

Rao, S. and Srivastava, S. 2000. Soil test based fertilizer use-a must for sustainable agriculture. Fertilizer News, 45:25-38.

Reddy, K.C. and Ahmed, S.R. 2000. Soil test based fertilizer recommendation for maize grown in inceptisols of Jagtiyal in Andra Pradesh. Journal of Indian Society of Soil Science. 48(1): 84-89.

Regar, K.L. and Singh, Y.V. 2014. Fertilizer recommendation based on soil testing for the targeted yield of rice in eastern plain zone of Uttar Pradesh. The Bioscan 9(2): 531-534.

Singh, A., Dass, A., Singh, C.V., Dhar, S., Sudhishri, S., Das, K. and Sarkar, S. K. 2017. Growth, productivity and nutrient concentration of aerobic rice (Oryza sativa L.) under different planting methods, irrigation schedules and soil adjuvant application. Ann. Agric. Res. 38 (4): 368-374.

Srivastava, O.P. 2013. Integrated nutrient management for sustained fertility of soil. Ind. J. Agric. Chem. 31(1): 1-12.

Subbiah, B.V. and Asija, G.L. 1956. A rapid method for the estimation of nitrogen in soils. Current Science 25: 259-260.

Subehia, S.K. and Sepehya, S. 2012. Influence of long-term nitrogen substitution through organics on yield, uptake and available nutrients in a ricewheat system in an acidic soil. Journal of the Indian Society of Soil Science 60 (3): 213-217.

Tabar, Y.S. 2012. Effect of Nitrogen and Phosphorus Fertilizer on spikelet Structure and yield in rice (Oryza sativa L). International Journal of Agriculture and Crop Sciences. Doi: IJACS/511/1204-1208.

Troug, E. 1960. Fifty years of soil testing. Transactions of $7^{\text {th }}$ International Congress of Soil Science, Vol. 3, Commission IV, Paper No. 7, 46-53.

Walkley, A. and Black, C.A. 1934. An examination to different method for determination soil organic matter and proposal for modification of the chromic acid titration method. Soil Science 37: 29-38.

\section{How to cite this article:}

Saroj Choudhary, S.S. Baghel, A.K. Upadhyay and Arjun Singh. 2019. STCR- Based Manure and Fertilizers Application Effect on Performance of Rice and Chemical Properties of Vertisol. Int.J.Curr.Microbiol.App.Sci. 8(03): 2080-2086. doi: https://doi.org/10.20546/ijcmas.2019.803.248 